LWSA

Local Wisdom, Social, and Arts

PAPER - OPEN ACCESS

Perbedaan Rumusan Ketentuan Penutup Dalam Berbagai Peratutan Perundang-Undangan di Indonesia dan Implikasi Hukumnya
Author
: Yusrin Yusrin
DOI
: 10.32734/lwsa.v1i1.162
Electronic ISSN
: 2654-7058
Print ISSN
: 2654-7066

Volume 1 Issue 1 - 2018 TALENTA Conference Series: Local Wisdom, Social and Arts

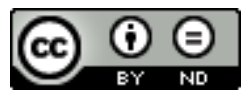

This work is licensed under a Creative Commons Attribution-NoDerivatives 4.0 International License.

Published under licence by TALENTA Publisher, Universitas Sumatera Utara
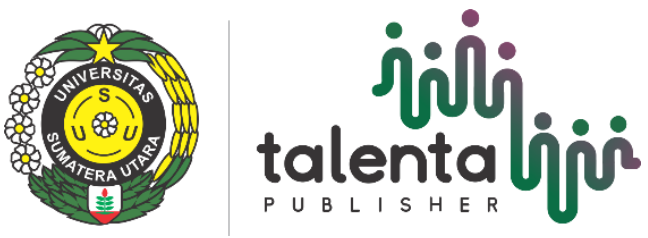


\title{
Perbedaan Rumusan Ketentuan Penutup Dalam Berbagai Peratutan Perundang-Undangan di Indonesia dan Implikasi Hukumnya
}

\author{
Yusrin $^{\mathrm{a}}$ \\ ${ }^{a}$ Fakultas Hukum, Universitas Sumatera Utara, Medan - 20155 \\ yusrinnazief@gmail.com
}

\begin{abstract}
Abstrak
Kebutuhan Indonesia akan peraturan perundang-undangan sebagai sumber hukum utama dalam penyelenggaraan pemerintahan cukup tinggi. Puluhan Undang-Undang beserta peraturan pelaksanaannya diberlakukan setiap tahun. Banyaknya jumlah peraturan perundang-undangan yang berlaku dapat memunculkan konflik antar peraturan perundang-undangan. Untuk menghindari konflik ini, 'Ketentuan Penutup' yang merupakan bagian utuh dari sebuah peraturan perundang-undangan dapat merumuskan hubungan peraturan perundang-undangan itu dengan berbagai peraturan perundang-undangan lainnya yang telah berlaku sebelumnya. Namun demikian, rumusan Ketentuan Penutup tidaklah sama dalam berbagai peraturan perundang-undangan yang ada. Perbedaan rumusan Ketentuan Penutup ini tentu akan memberikan implikasi hukum yang berbeda pula. Oleh karenanya perlu dilakukan penelitian terhadap variasi rumusan Ketentuan Penutup tersebut dan kajian tentang implikasi hukum atas perbedaan itu. Penelitian ini merupakan penelitian normatif dengan meneliti dan menganalisa undang-undang yang dikeluarkan setelah berlakunya Undang-Undang Nomor 12 Tahun 2011. Hasil penelitian menunjukkan bahwa variasi rumusan Ketentuan Penutup dalam menjelaskan hubungan dengan berbagai peraturan perundang-undangan yang telah ada terbagi atas empat model, yakni: pertama, menyatakan secara tegas mencabut peraturan perundang-undangan secara keseluruhan; kedua, menyatakan secara tegas mencabut peraturan perundang-undangan secara parsial; ketiga: memberlakukan secara bersyarat peraturan perundang-undangan secara keseluruhan, dan keempat: memberlakukan secara bersyarat peraturan perundang-undangan secara parsial. Perbedaan rumusan Ketentuan Penutup ini memberikan implikasi hukum yang berbeda pula. Karenanya rumusan Ketenttuan Penutup ini perlu diatur secara lebih rinci dalam Undang-Undang Pembentukan Peraturan Perundang-Undangan agar dapat dipahami oleh segenap penyelenggara negara dan masyarakat.
\end{abstract}

Kata Kunci: Ketentuan Penutup; peraturan perundang-undangan; pencabutan, pemberlakuan bersyarat

\section{Latar Belakang}

Indonesia sebagai salah satu negara yang mengikuti pola sistem hukum eropa kontinental (civil law system) sangat membutuhkan keberadaan peraturan perundang-undangan dalam penyelenggaraan negara. ${ }^{15}$ Peraturan perundangundangan menjadi rujukan utama dalam menentukan kewenangan berbagai lembaga negara dan lembaga pemerintahan, menjadi rujukan dalam mengambil kebijakan negara serta tindakan pemerintahan, dan sekaligus juga menjadi dasar untuk mempertahankan hak-hak warga negara ketika berhadapan dengan kekuasaan negara maupun ketika terjadi benturan hak antar warga negara. ${ }^{16}$ Keberadaan peraturan perundang-undangan sangat penting dalam 
kehidupan bermasyarakat dan bernegara di Indonesia sehingga setiap tahunnya terdapat berbagai peraturan perundangundangan baru yang diberlakukan, baik dari segi jumlah maupun jenisnya. ${ }^{17}$

Undang-Undang sebagai salah satu jenis peraturan perundang-undangan yang berlaku di Indonesia memiliki posisi yang sangat penting dalam tatanan peraturan perundang-undangan. Undang-Undang menjadi dasar hukum untuk dibentuknya berbagai peraturan perundang-undangan lainnya. Program Legislasi Nasional yang ditetapkan oleh Dewan Perwakilan Rakyat (DPR) Republik Indonesia ${ }^{18}$ untuk jangka lima tahun, 2015-2019, memunculkan 170 (seratus tujuh puluh) Rancangan Undang-Undang. Ini artinya bahwa rata-rata Undang-Undang yang perlu dibentuk setiap tahunnya adalah sebanyak 34 (tiga puluh empat) buah. Jika dibandingkan dengan lima tahun sebelumnya, 20102014, jumlah Undang-Undang yang telah dibentuk adalah sebanyak 127 (seratus dua puluh tujuh) buah. ${ }^{19}$

Banyaknya Undang-Undang yang dihasilkan per tahun tidak selalu memberikan manfaat bagi masyarakat, namun juga dapat menimbulkan permasalahan dalam tataran praktis. Bahkan dampak pemberlakuan banyaknya peraturan perundang-undangan dapat menimbulkan kesulitan bagi pelaksana pemerintahan. Presiden Republik Indonesia pada akhir Maret 2016 yang lalu menyatakan bahwa DPR tidak usah memproduksi undang-undang terlalu banyak, cukup tiga sampai lima saja setahun. ${ }^{20}$ Presiden menyampaikan harapannya agar Undang-Undang yang dihasilkan memiliki kuailtas yang baik, bukan sekedar kuantitas yang banyak. ${ }^{21}$

Peranyataan tersebut memberikan gambaran bahwa banyaknya Undang-Undang yang diberlakukan setiap tahunnya dapat menimbulkan dampak yang tidak baik dalam penyelenggaraan negara. Dampak lainnya adalah terjadinya perbedaan rumusan norma hukum antara Undang-Undang yang satu dengan Undang-Undang yang lainnya. Perbedaan tersebut juga dapat terjadi antara Undang-Undang dengan berbagai peraturan perundang-undangan lainnya. Perbedaan rumusan norma hukum antar berbagai peraturan perundang-undangan ini dapat menimbulkan konflik norma. ${ }^{22}$ Konflik norma dapat menyebabkan benturan kewenangan antar berbagai lembaga negara atau lembaga pemerintahan, tumpang tindihnya hak masyarakat, dan berbagai problematika hukum lainnya.

Problematika hukum yang muncul karena konflik norma atas berlakunya suatu peraturan perundang-undangan yang baru dapat diatasi dengan mencantumkan suatu ketentuan yang menjelaskan hubungan hukum antara peraturan perundang-undangan yang baru dengan berbagai peraturan perundang-undangan lainnya yang telah ada. Ketentuan mengenai hal ini dirumuskan pada bagian _Ketentuan Penutup' sebuah peraturan perundang-undangan. Namun demikian, rumusan Ketentuan Penutup dalam berbagai peraturan perundang-undangan yang ada tidaklah sama. Perbedaan ini tentu akan memberikan implikasi hukum yang beragam pula.

Perbedaan rumusan Ketentuan Penutup beserta implikasi hukumnya itu perlu diteliti dan dikaji lebih lanjut sehingga memberikan gambaran yang jelas. Kejelasan mengenai ragam rumusan Ketentuan Penutup beserta implikasi hukumnya itu akan sangat bermanfaat bagi masyarakat dan aoaratur pemerintahan secara umum, dan secara khusus memperkaya pengetahuan dalam lapangan Ilmu Pengetahuan Peraturan Perundang-undangan. Untuk itulah, penelitian ini dilakukan.

\section{Metode Penelitian}

Penelitian ini merupakan penelitian yuridis normatif. Penelitian ini mengidentifikasi ragam rumusan ketentuan penutup yang ada di dalam Undang-Undang. Fokus penelitian dilakukan terhadap Undang-Undang yang dikeluarkan setelah berlakunya Undang-Undang Nomor 12 Tahun 2011 tentang Pembentukan Peraturan Perundang-undangan, secara khusus dilakukan terhadap Undang-Undang yang diberlakukan mulai Januari 2014 hingga Juli 2016. UndangUndang tersebut sebagiannya disahkan oleh Presiden atas persetujuan bersama dengan DPR periode 2009-2014, dan sebagian lainnya merupakan persetujuan bersama dengan DPR periode 2014-2019. Jumlah Undang-Undang yang berlaku mulai Januari 2014 hingga Juli 2016 adalah sebanyak 68 (enam puluh delapan) buah. Ragam rumusan Ketentuan Penutup yang ditemukan dalam 68 undang-undang tersebut dikelompokkan berdasarkan kesamaan pola yang digunakan. Pengelompokan ini dimaksudkan untuk mendapatkan gambaran mengenai berapa banyak jumlah pola rumusan Ketentuan Penutup yang ada dalam praktek pembentukan peraturan perundang-undangan. Perbedaan rumusan itu selanjutnya dianalisa guna menilai implikasi hukum apa saja yang muncul dari masing-masing pola rumusan yang ada. 


\section{Konsepsi Hukum Terkait}

Konsepsi hukum berikut ini diperlukan untuk mendiskusikan lebih lanjut implikasi hukum atas beragamnya rumusan Ketentuan Penutup yang ada dalam berbagai undang-undang.

\subsection{Peraturan Perundang-Undangan}

Defenisi peraturan perundang-undangan dapat dirujuk pada Pasal 1 angka 2 Undang-Undang Nomor 12 Tahun 2011. Undang-undang ini mendefenisikan : - Peraturan Perundang-undangan adalah peraturan tertulis yang memuat norma hukum yang mengikat secara umum dan dibentuk atau ditetapkan oleh lembaga negara atau pejabat yang berwenang melalui prosedur yang ditetapkan dalam Peraturan Perundang-undangan.\| Dari defenisi ini, ada empat unsur yang menjadi pembentuk sebuah peraturan perundang-undangan. Unsur-unsur tersebut adalah: (1) merupakan peraturan tertulis; (2) memuat norma hukum yang bersifat umum; (3) dibentuk oleh lembaga negara atau pejabat yang berwenang; (4) melalui prosedur yang berlaku. Keempat unsur tersebut merupakan ukuran untuk menentukan apakah sebuah produk hukum dapat dikategorikan sebagai peraturan perundang-undangan ataukah tidak. Jika tidak memenuhi keempat unsur tersebut maka produk hukum itu kemungkinan merupakan peraturan saja atau sama sekali bukan peraturan

\subsection{Ketentuan Penutup}

Ketentuan Penutup adalah bagian utuh dari sebuah peraturan perundang-undangan. Ketentuan Penutup bukanlah klausul yang bersifat alternatif yang keberadaannya hanya jika diperlukan, namun ia merupakan komponen wajib yang harus ada dalam sebuah peraturan perundang-undangan. Ketentuan Penutup merupakan bagian terakhir yang terdapat pada Batang Tubuh sebuah peraturan perundang-undangan, dan jika sebuah peraturan perundang-undangan memiliki ketentuan pidana dan/atau ketentuan peralihan maka Ketentuan Penutup ditempatkan setelahnya. Ketentuan Penutup dapat dirumuskan dalam sebuah Bab tersendiri maupun juga hanya dirumuskan dalam satu atau beberapa pasal (jika tidak ada pengelompokan bab dalam peraturan perundang-undangan tersebut). ${ }^{23}$ Berbeda dengan beberapa klausul lainnya yang bersifat alternatif (seperti ketentuan pidana, ketentuan peralihan, penjelasan, dan lampiran), Ketentuan Penutup bersifat wajib dan mengandung beberapa konsepsi penting. Karena itulah, pemahaman terhadap Ketentuan Penutup dan konsepsi yang terkait dengannya sangat diperlukan agar pelaksanaan peraturan perundang-undangan menjadi lebih baik. Ketentuan Penutup, menurut Jimly Asshiddiqie, pada umumnya memuat empat hal, walalupun tidaklah harus keempat hal tersebut ada pada Ketentuan Penutup semua peraturan perundang-undangan. ${ }^{24}$ Dari empat hal yang umumnya dirumuskan dalam Ketentuan Penutup tersebut, fokus penelitian hanya ditujukan untuk mendalami satu diantaranya, yaitu mengenai status peraturan perundang-undangan yang sudah ada sebelumnya.

\section{Online license transfer}

Ketentuan Penutup yang terdapat dalam 68 Undang-Undang yang diteliti menunjukkan adanya keragaman rumusan. Ada empat model rumusan Ketentuan Penutup yang menggambarkan hubungan undang-undang yang baru dengan peraturan perundang-undangan yang telah ada sebelumnya, baik hubungannya dengan undang-undang maupun juga hubungan dengan peraturan perundang-undangan lain yang bukan undang-undang. Keempat model tersebut akan diuraikan satu-persatu berikut ini.

\subsection{Pencabutan Peraturan Perundang-undangan Secara Keseluruhan}

Pencabutan peraturan perundang-undangan secara keseluruhan dirumuskan dengan hanya menyebut judul ' dari peraturan perundang-undangan yang dimaksud tanpa merinci atau merujuk kepada pasal per pasal atau ketentuan tertentu dari satu atau beberapa peraturan perundang-undangan. Contoh hal ini sebagaimana terdapat pada Pasal 151 Undang-Undang Nomor 8 Tahun 2016 tentang Penyandang Disabilitas: -Pada saat Undang-Undang ini mulai berlaku, Undang-Undang Nomor 4 Tahun 1997 tentang Penyandang Cacat (Lembaran Negara Republik Indonesia 
Tahun 1997 Nomor 9, Tambahan Lembaran Negara Republik Indonesia Nomor 3670), dicabut dan dinyatakan tidak berlakull. Pasal 151 tersebut secara jelas mencabut Undang-Undang Nomor 4 Tahun 1997 tentang Penyandang Cacat, sehingga semua ketentuan yang terdapat dalam Undang-Undang itu menjadi tidak berlaku lagi.

\subsection{Pencabutan Peraturan Perundang-undangan Secara Parsial}

Pencabutan peraturan perundang-undangan secara parsial dirumuskan dengan menyebut secara khusus bagian dari peraturan perundang-undangan yang dicabut (baik pasal per pasal ataupun ketentuan tertentu). Contoh hal ini sebagaimana terdapat pada Ketentuan Penutup Undang-Undang Nomor 6 Tahun 2014 tentang Desa, Pasal 121 menentukan: -Pada saat Undang-Undang ini mulai berlaku, Pasal 200 sampai dengan Pasal 216 Undang-Undang Nomor 32 Tahun 2004 tentang Pemerintahan Daerah (Lembaran Negara Republik Indonesia Tahun 2004 Nomor 125, Tambahan Lembaran Negara Republik Indonesia Nomor 4437) sebagaimana telah diubah beberapa kali terakhir dengan Undang-Undang Nomor 12 Tahun 2008 tentang Perubahan Kedua atas Undang-Undang Nomor 32 Tahun 2004 tentang Pemerintahan Daerah (Lembaran Negara Republik Indonesia Tahun 2008 Nomor 59, Tambahan Lembaran Negara Republik Indonesia Nomor 4844) dicabut dan dinyatakan tidak berlakull.

Pada Pasal 121 tersebut yang dicabut adalah sebagian dari Undang-Undang Nomor 32 Tahun 2004 tentang Pemerintahan Daerah, yakni ketentuan yang terdapat pada Pasal 200 sampai dengan Pasal 216, jadi bukan keseluruhan isi dari Undang-Undang Nomor 32 Tahun 2004 tersebut yang dicabut. Namun demikian, dalam penelitian tidak ditemukan adanya pencabutan peraturan perundang-undangan secara parsial terhadap peraturan perundang-undangan yang lebih rendah tingkatannya dari undang-undang ataupun peraturan pelaksananya.

\subsection{Pemberlakuan Bersyarat Peraturan Perundang-undangan Secara Keseluruhan}

Pemberlakuan bersyarat peraturan perundang-undangan secara keseluruhan dirumuskan dengan menyebut nama dari peraturan perundang-undangan tanpa menyebut nomor dan tahun. Dengan kata lain, yang dirumuskan dalam Ketentuan Penutup adalah perihal yang diatur oleh peraturan perundang-undangan. Contoh hal ini sebagaimana terdapat pada Ketentuan Penutup Undang-Undang Nomor 1 Tahun 2016 tentang Penjaminan, Pasal 63 menentukan: -Pada saat Undang-Undang ini mulai berlaku, semua peraturan perundang-undangan mengenai penjaminan dinyatakan masih tetap berlaku sepanjang tidak bertentangan dengan ketentuan dalam Undang-Undang inill. Peraturan perundang-undangan yang dimaksud pada Pasal 63 tersebut adalah secara keseluruhan serta tidak dibatasi pada hirarki yang sama atau lebih rendah saja, tetapi meliputi keseluruhannya (hirarkinya sama ataupun lebih rendah).

\subsection{Pemberlakuan Bersyarat Perundang-undangan Secara Parsial}

Pemberlakuan bersyarat perundang-undangan secara parsial menyebutkan secara khusus bagian dari peraturan perundang-undangan yang dimaksud (baik pasal per pasal ataupun ketentuan tertentu). Contoh hal ini sebagaimana terdapat pada Ketentuan Penutup Undang-Undang Nomor 7 Tahun 2016 tentang Perlindungan dan Pemberdayaan Nelayan, Pembudi Daya Ikan, dan Petambak Garam, Pasal 76 menentukan: -Pada saat Undang-Undang ini mulai berlaku, semua ketentuan peraturan perundang- undangan yang mengatur Perlindungan dan Pemberdayaan Nelayan, Pembudi Daya Ikan, dan Petambak Garam dinyatakan masih tetap berlaku sepanjang tidak bertentangan dengan ketentuan dalam Undang-Undang inill.

Pasal 76 ini dikategorikan sebagai pemberlakuan bersyarat peraturan perundang-undangan secara parsial dikarenakan yang diberlakukan adalah — ketentuan peraturan perundang-undanganll terhadap hal khusus (yakni yang mengatur Perlindungan dan Pemberdayaan Nelayan, Pembudi Daya Ikan, dan Petambak Garam), bukan dimaksudkan kepada satu atau beberapa peraturan perundan-undangan secara utuh. Makna phrasa - ketentuan peraturan perundangundangan $\|$ adalah bagian dari sebuah peratturan perundang-undangan. Bisa saja peraturan perundang-undangannya tidak spesifik tentang Perlindungan dan Pemberdayaan Nelayan, Pembudi Daya Ikan, dan Petambak Garam, namun di dalam peraturan perundang-undangan itu terdapat ketentuan yang mengatur tentang Perlindungan dan Pemberdayaan Nelayan, Pembudi Daya Ikan, dan Petambak Garam. 
Dari keempat model rumusan Ketentuan Penutup tersebut, beberapa hal yang tergambar secara jelas adalah:

1. Pencabutan peraturan perundang-undangan secara keseluruhan harus menyebutkan secara jelas judul dari peraturan perundang-undangan dimaksud. Jika pencabutan tersebut hanya bersifat parsial maka bagian tertentunya (pasal atau ketentuan) harus dinyatakan secara pasti pula sehingga tidak akan menimbulkan perdebatan tentang normanorma hukum apa saja yang tidak berlaku karena pencabutan itu.

2. Pemberlakuan bersyarat peraturan perundang-undangan, baik secara keseluruhan maupun parsial, tidak menyebutkan judul dari peraturan perundang-undangan dimaksud. Rumusannya dapat dilakukan dengan hanya menyebutkan hal yang diatur dalam suatu ketentuan ataupun tema yang diatur dalam peraturan perundangundangan tersebut sehingga sangat mungkin tafsiran atas pasal atau ketentuan mana sajakah yang masih berlaku dan tidak dapat berlaku lagi akan menjadi sebuah perdebatan.

3. Redaksi ketentuan penutup yang menyatakan pemberlakuan bersyarat suatu peraturan perundang-undangan menggunakan kata - ketentuanl sebelum menyebut peraturan perundang-undangan yang diberlakukan bersyarat. Misalnya : - Pada saat Undang-Undang ini mulai berlaku, semua ketentuan peraturan . . . dinyatakan masih tetap berlaku sepanjang tidak bertentangan dengan ketentuan dalam Undang-Undang inill. Sementara untuk pemberlakuan bersyarat secara menyeluruh tidak menggunakan kata — ketentuanll. Misalnya : -Pada saat UndangUndang ini mulai berlaku, semua peraturan. . . dinyatakan masih tetap berlaku sepanjang tidak bertentangan dengan ketentuan dalam Undang-Undang ini.\|

\section{Implikasi Hukum Atas Perbedaan Rumusan Ketentuan Penutup}

Perbedaan rumusan Ketentuan Penutup dalam menentukan status peraturan perundang-undangan yang telah berlaku terlebih dahulu menimbulkan implikasi hukum yang berbeda-beda pula. Implikasi hukum yang dimaksud diuraikan dalam dua kategori, yakni pencabutan dan pemberlakuan bersyarat. Implikasi hukum yang dibahas berikut ini walaupun berawal dari rumusan ketentuan penutup dalam Undang-Undang namun konsepsi hukum yang didiskusikan ditujukan secara umum untuk semua Ketentuan Penutup dalam berbagai jenis peraturan perundang-undangan.

\subsection{Implikasi Pencabutan Peraturan Perundang-undangan}

Tidak ada perbedaan implikasi hukum yang signifikan antara Pencabutan suatu peraturan perundang-undangan secara parsial maupun menyeluruh. Pencabutan suatu peraturan perundang-undangan mengakibatkan norma hukum yang terkandung di dalam peraturan perundang-undangan itu menjadi tidak berlaku lagi. Jika pencabutan dilakukan secara menyeluruh maka seluruh norma hukum dari peraturan perundang-undangan yang dicabut menjadi tidak berlaku. Sementara jika pencabutan dilakukan secara parsial maka hanya norma hukum tertentu saja yang tidak berlaku, sementara peraturannya masih berlaku karena ada norma hukum lain yang masih tetap berlaku. ${ }^{25}$ Norma hukum yang tidak berlaku lagi itu tidak dapat menjadi dasar untuk perbuatan hukum ke depannya, tidak dapat mengikat masyarakat, dan tidak ada kewenangan yang disandarkan kepadanya. Pencabutan peraturan perundang-undangan menentukan secara pasti ketentuan atau peraturan yang dicabut sehingga tidak menimbulkan perdebatan tentang norma-norma hukum itu ke depannya. Namun demikian, segala hubungan hukum yang ditimbulkan dari pelaksanaan norma hukum sebelum ia dicabut harus tetap dianggap sah. Pemberlakuan norma hukum sebelum dilakukan pencabutan, dalam hal tertentu seperti perjanjian, akan terus menimbulkan hubungan hukum yang tidak dapat begitu saja berhenti seiring pencabutannya. Status hubungan hukum seperti ini akan menjadi persoalan hukum baru yang dapat berujung kepada sengketa. ${ }^{26}$ Salah satu upaya untuk mengatasi hal seperti ini dapat dilakukan dengan menjelaskan hal itu dalam Ketentuan Peralihan sebuah peraturan perundang-undangan. Ketentuan Peralihan ini dapat merumuskan solusi untuk hal tersebut, yang diantaranya meliputi pemberian perlindungan hukum bagi pihak yang terkena dampak pencabutan dan menjamin adanya kepastian hukum. ${ }^{27}$ Subjek hukum yang memiliki iktikad baik yang memiliki hak karena perizinan atau perjanjian sebelum rezim hukum baru diberlakukan harus dilindungi akibat terjadinya perubahan hukum. ${ }^{28}$ 


\subsection{Implikasi Pemberlakuan Bersyarat Peraturan Perundang-undangan}

Berbeda dengan pencabutan peraturan perundang-undangan yang tidak memiliki perbedaan implikasi hukum yang signifikan antara pencabutan yang menyeluruh dan yang parsial, dalam hal pemberlakuan bersyarat peraturan perundang-undangan akan menimbulkan implikasi hukum yang berbeda antara yang menyeluruh dengan yang parsial dan lebih komplikatif. Jika pemberlakuan bersyarat peraturan perundang-undangan dilakukan secara parsial (hanya menunjuk ketentuan-ketentuan tertentu saja), maka apabila syarat yang dinyatakan dalam Ketentuan Penutup tidak terpenuhi (yakni justeru bertentangan) akibatnya adalah ketentuan-ketentuan tertentu tersebut menjadi tidak berlaku. Implikasi hukum yang timbul karena tidak terpenuhinya syarat yang ditentukan dalam ketentuan penutup adalah sama dengan seperti pencabutan parsial. Sementara jika pemberlakuan bersyarat peraturan perundang-undangan dilakukan secara menyeluruh, maka apabila syarat yang dinyatakan dalam Ketentuan Penutup tidak terpenuhi akibatnya adalah seluruh peraturan perundang-undangan itu menjadi tidak berlaku, sekalipum hanya sebagian ketentuan dari peraturan perundang-undangan itu yang tidak memenuhi persyaratan ketentuan penutup.

Hanya saja, pemberlakuan bersyarat sebuah peraturan perundang-undangan memunculkan satu persoalan hukum penting yang patut dicermati, yakni bagaimana jika terdapat perbedaan pandangan tentang terpenuhi ataukah tidak terpenuhinya syarat yang ditentukan dalam Ketentuan Penutup. Atau dengan kata lain, siapakah yang berhak menentukan apakah suatu peraturan perundang-undangan yang diberlakukan bersyarat itu bertentangan ataukah tidak bertentangan dengan peraturan perundang-undangan yang memberikan pemberlakuan bersyarat itu?

Penentuan mengenai bertentangan ataukah tidak bertentangan suatu peraturan perundang-undangan dengan peraturan perundang-undangan yang memberikan pemberlakuan bersyarat terhadapnya dapat dihasilkan melalui prosedur internal review ataupun external review. Internal review adalah penilaian suatu peraturan perundangundangan yang dilakukan oleh lembaga atau pejabat yang membuatnya atau memberlakukannya. Internal review ini dapat berbentuk legislative review maupun executive review. ${ }^{29}$ External review dilakukan oleh badan peradilan. External review ini umumnya dilakukan melalui proses judicial review. ${ }^{30}$

Internal review yang dilakukan lembaga atau pejabat yang membuat peraturan perundang-undangan bukanlah satusatunya ukuran untuk menentukan kesesuaian suatu peraturan perundang-undangan yang diberlakukan secara bersyarat dengan peraturan perundang-undangan yang memberikan pemberlakuan bersyarat itu. Adakalanya, lembaga atau pejabat tersebut tidak berkenan untuk melakukan perubahan terhadap peraturan perundang-undangan yang telah diberlakukannya sekalipun mengandung pertentangan dengan peraturan rujukannya. ${ }^{31} \mathrm{Jikalau}$ hal ini terjadi maka ada dua pilihan yang dapat dilakukan. Pertama, jika hal itu berkaitan dengan peralihan kewenangan, maka lembaga yang mendapatkan kewenangan dari sebuah peraturan perundang-undangan yang baru dapat menjalankan kewenanganya itu tanpa menunggu mau atau tidak mau lembaga yang lama menyerahkan atau melepaskan kewenangannya. Pilihan kedua, penilaian terhadap kesesuaian itu dapat dimintakan kepada lembaga lain melalui prosedur judicial review.

\section{Penutup}

Berdasarkan hasil penelitian sebagaimana diuraikan pada bagian sebelumnya, keempat model rumusan Ketentuan Penutup Undang-Undang dalam menjelaskan status peraturan perundang-undangan lainnya yang telah berlaku sebelumnya menimbulkan implikasi hukum yang berbeda. Sebagian implikasi hukum tersebut menjadi komplikatif sehingga berpotensi untuk menjadi persoalan hukum dalam tataran praktis. Hal ini tentu tidak sejalan dengan tujuan yang ingin dicapai dari adanya Ketentuan Penutup dalam sebuah peraturan perundang-undangan. Ada baiknya hal-hal yang berpotensi sebagai perdebatan dalam menjalankan rumusan Ketentuan Penutup lebih diuraikan dalam pedoman pembentukan peraturan perundang-undangan dalam Undang-Undang Pembentukan Peraturan Perundang-undangan. Penilitian ini merekomendasikan untuk diadakannya penelitian lanjutan yang lebih komprehensif, baik terhadap undang-undang yang diberlakukan sebelum tahun 2014, maupun terhadap jenis peraturan perundang-undangan lainnya.

\section{Referensi}

[1] Fatmawati (2005), Hak Menguji (Toetsingsrecht) yang Dimiliki Hakim Dalam Sistem Hukum Indonesia, RajaGrafindo Persada, Jakarta. 
[2] Hans Kelsen, (1995), Teori Hukum Murni - Dasar-Dasar Ilmu Hukum Normatif Sebagai Ilmu Hukum Empirik Deskriptif (terjemahan), Rimdi Press.

[3] Jimly Asshiddiqie, (2014), Peradilan Etik Dan Etika Konstitusi - Perspektif Baru tentang _Rule of Law and Rule of Ethics` \& Constitutional Law and Constitutional Ethics', Sinar Grafika, Jakarta.

[4] Jimly Asshiddiqie, (2006), Perihal Undang-Undang, Konstitusi Press, Jakarta

[5] Jimly Asshiddiqie, (2005), Hukum Acara Pengujian Undang-Undang, Yarsif Watampone, Jakarta.

[6] Joseph Dainow, - The Civil Law and The Common Law : Some Points of Comparisonll, The American Journal of Comparative Law, Vol.15 No.3.

[7] Zainal, (2009), Judicial Review di Mahkamah Agung RI - Tiga Dekade Pengujian Peraturan Perundang-undangan, RajaGrafindo Persada, Jakarta.

[8] Undang-Undang Nomor 12 Tahun 2011 tentang Pembentukan Peraturan Perundang-undangan (Lembaran Negara Republik Indonesia Tahun 2011 Nomor 82, Tambahan Lembaran Negara Republik Indonesia Nomor 5234.

[9] Putusan Mahkamah Konstitusi Republik Indonesia Perkara Nomor 013/PUU-I/2003.

[10] Putusan Mahkamah Konstitusi Republik Indonesia Perkara Nomor 018/PUU-I/2003 .

[11] Putusan Mahkamah Konstitusi Republik Indonesia Perkara Nomor 13/PUU-VI/2008. 